Louisiana State University

LSU Digital Commons

$7-28-2008$

\title{
Homolytic bond strengths and formation rates in half-sandwich chromium alkyl complexes: Relevance for controlled radical polymerization
}

\author{
Yohan Champouret \\ Institut National Polytechnique de Toulouse \\ Ulrich Baisch \\ Institut National Polytechnique de Toulouse \\ Rinaldo Poli \\ Institut National Polytechnique de Toulouse \\ Liming Tang \\ University of Prince Edward Island \\ Julia L. Conway \\ University of Prince Edward Island
}

See next page for additional authors

Follow this and additional works at: https://digitalcommons.Isu.edu/chemistry_pubs

\section{Recommended Citation}

Champouret, Y., Baisch, U., Poli, R., Tang, L., Conway, J., \& Smith, K. (2008). Homolytic bond strengths and formation rates in half-sandwich chromium alkyl complexes: Relevance for controlled radical polymerization. Angewandte Chemie - International Edition, 47 (32), 6069-6072. https://doi.org/10.1002/ anie. 200801498

This Article is brought to you for free and open access by the Department of Chemistry at LSU Digital Commons. It has been accepted for inclusion in Faculty Publications by an authorized administrator of LSU Digital Commons. For more information, please contact ir@lsu.edu. 


\section{Authors}

Yohan Champouret, Ulrich Baisch, Rinaldo Poli, Liming Tang, Julia L. Conway, and Kevin M. Smith 
archives-ouvertes

\title{
Homolytic Bond Strengths and Formation Rates in Half-Sandwich Chromium Alkyl Complexes: Relevance for Controlled Radical Polymerization
}

\author{
Yohan Champouret, Ulrich Baisch, Rinaldo Poli, Liming Tang, Julia 1.
}

Conway, Kevin m. Smith

\section{To cite this version:}

Yohan Champouret, Ulrich Baisch, Rinaldo Poli, Liming Tang, Julia l. Conway, et al.. Homolytic Bond Strengths and Formation Rates in Half-Sandwich Chromium Alkyl Complexes: Relevance for Controlled Radical Polymerization. Angewandte Chemie International Edition, Wiley-VCH Verlag, 2008, 47 (32), pp.6069-6072. 10.1002/anie.200801498 . hal-03192514

\section{HAL Id: hal-03192514 \\ https://hal.archives-ouvertes.fr/hal-03192514}

Submitted on 8 Apr 2021

HAL is a multi-disciplinary open access archive for the deposit and dissemination of scientific research documents, whether they are published or not. The documents may come from teaching and research institutions in France or abroad, or from public or private research centers.
L'archive ouverte pluridisciplinaire HAL, est destinée au dépôt et à la diffusion de documents scientifiques de niveau recherche, publiés ou non, émanant des établissements d'enseignement et de recherche français ou étrangers, des laboratoires publics ou privés. 


\title{
Homolytic bond strengths and formation rates in half-sandwich chrom- ium-alkyl complexes: relevance for controlled radical polymerization $* *$
}

\author{
Yohan Champouret, Ulrich Baisch, Rinaldo Poli, * Liming Tang, Julia L. Conway, Kevin M. Smith, *
}

This last decade, controlled/living radical polymerization (CRP) processes have seen a considerable surge of interest due, in part, to their relevance to access to a variety of well-defined polymer structures (e.g. predetermined molecular mass, narrow molecular weight distribution). ${ }^{[1]} \mathrm{We}$ have been interested in one-electron reactivity of transition metal complexes and its relevance in CRP. ${ }^{[2]}$ One way in which transition metal complexes can be used to control radical polymerization is through a reversible deactivation consisting of the formation of an organometallic dormant species, a metal-capped polymer chain, by trapping the growing radical chain with formation of a metal-carbon bond, see Figure 1. We refer to this particular control mechanism as "organometallic radical polymerization" (OMRP). ${ }^{[2]}$ One of the outstanding challenges in this area is the possibility to control the polymerization of less reactive monomers (e.g. vinyl chloride, vinylidene dichloride, vinyl acetate, etc.), for which activation is made difficult by the relative strong bonds established with the common radical traps.

Reasonable control for the radical propagation of poly(vinyl acetate) (PVAc) has been achieved on the basis of another control mechanist (degenerative transfer, DT, based on the use of xanthates or dithiocarbamates). ${ }^{[3,4]}$ Results obtained by atom transfer radical polymerization (ATRP) have not been nearly as good, ${ }^{[5-7]}$ while good control was recently achieved in the presence of $\mathrm{Co}(\mathrm{acac})_{2}$ $\left(M_{w} / M_{n}\right.$ as low as 1.1).$^{[8,9]}$ Recent studies carried out partly in one of our laboratories have shown that this process occurs either by DT or

[*] Dr. Ulrich Baisch, Prof. Rinaldo Poli Laboratoire de Chimie de Coordination, UPR CNRS 8241 liée par convention à l'Université Paul Sabatier et à l'Institut National Polytechnique de Toulouse 205 Route de Narbonne, 31077 Toulouse Cedex, France. Fax: +33-561553003

E-mail: Rinaldo.Poli@lcc-toulouse.fr

Homepage: http://www.lcctoulouse.fr/equipe g/pages personnelles/poli/index.html

Dr. Liming Tang, Ms. Julia L. Conway, Prof. Kevin M. Smith Department of Chemistry University of Prince Edward Island 550 University Avenue, Charlottetown, PE, Canada, V6T $1 \mathrm{Z1}$

[†] Current address: Department of Chemistry, UBC Okanagan 3333 University Way, Kelowna, BC, Canada V1V 1V7

Fax: +1.250 .807 .8005$

E-mail: kevin.m.smith@ubc.ca Homepage:

http://web.ubc.ca/okanagan/chees/faculty/kmsmith.htm/

[**] RP thanks the ANR (contract No. NT05-2_42140) and IUF for financial support and the CICT (Project CALMIP) for granting free computational time, and KMS thanks NSERC of Canada for financial support and Dr. Brian O. Patrick (UBC) for performing the single crystal X-ray structural determinations and refinements. by OMRP depending on the presence of additional ligands such as pyridine or water. ${ }^{[10,11]}$

\section{$<$ Figure 1>}

In search for other transition metal complexes capable of controlling the polymerization of less reactive monomers, we have considered the use of half-sandwich $\beta$-diketiminato system of $\mathrm{Cr}^{\mathrm{II}}$, or the type shown in Scheme 1. Previous studies have shown that stable $\mathrm{Cr}^{\mathrm{III}}$ complexes with methyl ligands can be prepared by oxidation of $\mathbf{1}$ with silver triflate, followed by alkylation with methyl lithium, ${ }^{[12]}$ similar to the preparation of related chromium $\beta$ diketiminato organometallic complexes. ${ }^{[13-15]}$ However, attempts to synthesize half-sandwich $\mathrm{Cr}^{\mathrm{III}}$ complexes with larger alkyl ligands led to unexpected products presumably resulting from homolysis of the $\mathrm{Cr}^{\mathrm{III}}$-alkyl bond and subsequent hydrogen atom abstraction reactions of the solvent. ${ }^{[16]}$ Thus, this metal system shows promise for applications in OMRP. In this report, we will show by a combination of experimental and computational methods that the $\mathrm{Cr}^{\mathrm{III}}$-PVAc bond strength is dramatically influenced by the steric effect of the $\beta$-diketiminato aryl substituents and can be tuned to a suitable range for the CRP of the vinyl acetate monomer (VAc). Early reports of the use of $\mathrm{Cr}^{\mathrm{II}}$ acetate and benzoyl peroxide for controlled radical polymerization were discussed on the basis of what we now call an OMRP mechanism, but the polymerization activity was low for vinyl acetate. ${ }^{[17-19]}$

In addition to the already known ${ }^{[12]}$ compound $\mathrm{CpCr}^{\mathrm{II}}\left[\mathrm{Ar}^{1} \mathrm{NC}\right.$ $\left.\left(\mathrm{CH}_{3}\right) \mathrm{CHC}\left(\mathrm{CH}_{3}\right) \mathrm{NAr}^{2}\right]$ with $\mathrm{Ar}^{1}=\mathrm{Ar}^{2}=i \operatorname{Pr}_{2} \mathrm{C}_{6} \mathrm{H}_{3}$ (Dipp), 1, we have now prepared the analogue with $\mathrm{Ar}^{1}=\mathrm{Ar}^{2}=2,6-\mathrm{Me}_{2} \mathrm{C}_{6} \mathrm{H}_{3}$ (Xyl), 2, as well as asymmetric analogues with $\mathrm{Ar}^{1}=\mathrm{Dipp}$ and $\mathrm{Ar}^{2}$ $=\mathrm{Ph}(\mathbf{3}), p-\mathrm{C}_{6} \mathrm{H}_{4} \mathrm{OMe}(\mathbf{4})$, and $p-\mathrm{C}_{6} \mathrm{H}_{4} \mathrm{CF}_{3}$, (5). The structures of complexes $2, \mathbf{4}$ and 5 have been confirmed using single crystal Xray diffraction. Synthetic and structural details are provided in the supporting information.

\section{$\langle$ Scheme 1>}

Initial studies showed that compound $\mathbf{2}$ traps the growing polystyrene (PS) radical chain inefficiently. Indeed, the V-70initiated polymerization in the presence of $\mathbf{2}$ [bulk; styrene/V-70/2 = 250:0.8:1; V-70 = 2,2'-azobis(4-methoxy-2,4-dimethylvaleronitrile)] gave PDI $=2.5-3.7$, and a final polymer with $M_{\mathrm{n}}=7.9 \cdot 10^{4} \mathrm{~g} / \mathrm{mol}$ $\left(M_{n \text { (th. })}=1.7 \cdot 10^{4} \mathrm{~g} / \mathrm{mol}\right)$ at $65 \%$ conversion (additional data are presented in the Supporting Information). Since the growing PVAc radical is expected to establish a stronger bond that the growing PS radical, ${ }^{[20,21]}$ we anticipated a more efficient radical trapping for the growing PVAc radical chain.

In agreement with the above expectation, a preliminary screening of VAc polymerization initiated by V-70 in the presence of 2 at $50^{\circ} \mathrm{C}(\mathrm{VAc} / \mathbf{2} / \mathrm{V}-70=500 / 1 / 0.8)$ yielded essentially no polymer in $4 \mathrm{~h}$ (ca. 6 half-lives of V-70). Subsequent warming to $90^{\circ} \mathrm{C}$ yielded an initial polymerization $(11 \%$ conversion after an additional $4 \mathrm{~h}$ ), and then essentially no further conversion in the 
following $60 \mathrm{~h}\left(M_{n}=1.12 \cdot 10^{4} \mathrm{~g} / \mathrm{mol}, M_{w} / M_{n}=1.68\right.$ at $12 \%$ conversion; $\left.M_{n(\text { th. })}=5.16 \cdot 10^{3}\right)$, see Table 1 , showing a weak propensity for the $\mathrm{Cp}\left[\mathrm{XylNC}\left(\mathrm{CH}_{3}\right) \mathrm{CHC}\left(\mathrm{CH}_{3}\right) \mathrm{NXyl}\right] \mathrm{Cr}^{\mathrm{III}}-\mathrm{PVAc}$ bond to break homolytically.

\section{$<$ Table 1>}

With the idea in mind that the CrIII-PVAc BDE could be weakened by a greater ligand steric bulk, we turned our attention to compound 1. Indeed, when an experiment was carried out with complex $\mathbf{1}$ at $50^{\circ} \mathrm{C}$ in the presence of $\mathrm{V}-70(\mathrm{VAc} / \mathbf{1} / \mathrm{V}-70=500 / 1 / 0.8)$, the conversion reached $70 \%$ after only $20 \mathrm{~h}$, but control of the polymerization was poor $\left(M_{n}=5.67 \cdot 10^{4} \mathrm{~g} / \mathrm{mol} ; M_{w} / M_{n}=2.5 ; M_{n \text { (th. }}\right.$ $=3.01 \cdot 10^{4} \mathrm{~g} / \mathrm{mol}$ ), suggesting that the reversible trapping equilibrium of Figure 1 is not sufficiently displaced toward the dormant state under these conditions. Upon running the same process at lower temperature $\left(\mathrm{VAc} / \mathbf{1} / \mathrm{V}-70=500 / 1 / 0.8\right.$ at $\left.30^{\circ} \mathrm{C}\right)$, the polymerization was slower, see Table $1\left(k_{\text {app }}=3.3 \cdot 10^{-6} \mathrm{~s}^{-1}\right)$. Although the level of control is not yet ideal (at 70\% conversion: $M_{n}$ $=6.73 \cdot 10^{4} \mathrm{~g} / \mathrm{mol}, M_{v} / M_{n}=1.80, M_{n \text { (th.) }}=3.01 \cdot 10^{4} \mathrm{~g} / \mathrm{mol}$ ), the continuous growth of $M_{n}$ demonstrates the occurrence of an OMRP process. When the same experiment was run in the presence of a larger excess of V-70 (VAc/V-70/1 = 500:1.5:1), the polymerization was faster an uncontrolled. This result clearly shows that, contrary to the $\mathrm{Co}$ (porphyrin) $)^{[22]}$ and $\mathrm{Co}(\mathrm{acac})_{2}{ }^{[10]}$ systems, the present $\mathrm{Cr}^{\mathrm{II}}$ complex is not capable of mediating an associative DT process, consistent with the absence of vacant sites on the $\mathrm{Cr}$ atom in the $\mathrm{Cr}^{\mathrm{III}}$-capped dormant chain to promote an associative radical exchange.

The effect of the ligand steric encumbrance (Xyl vs. Dipp) and of the alkyl nature (PS $v s$. PVAc) on the $\mathrm{Cr}^{\mathrm{III}}-\mathrm{C}$ BDE was probed by DFT calculations on system $\mathrm{CpCr}{ }^{\mathrm{III}}\left[\mathrm{ArNC}\left(\mathrm{CH}_{3}\right) \mathrm{CHC}\left(\mathrm{CH}_{3}\right) \mathrm{NAr}\right](\mathrm{R})$, where $\mathrm{Ar}=\mathrm{Ph}$ or $\mathrm{Xyl}$ and $\mathrm{R}=\mathrm{CH}_{2} \mathrm{Ph}, \mathrm{CHMePh}$ (a model of the PS growing chain) and $\mathrm{CHMeOOCMe} \mathrm{(a} \mathrm{model} \mathrm{of} \mathrm{the} \mathrm{growing} \mathrm{PVAc}$ chain). All calculations were carried out by full QM, thus we avoided the larger Dipp-substituted $\beta$-diketiminato system, the steric effects being conveniently probed by the comparison of $\mathrm{Ph}$ and $\mathrm{Xyl}$ systems. Amongst different rotamers, the lowest energy ones are those where the $\mathrm{Ph}$ or OOCMe group is oriented endo relative to the $\mathrm{Cp}$ ring, as shown in Figure 2. The optimized geometries of the separate $\mathrm{CpCr}{ }^{\mathrm{II}}\left[\mathrm{ArNC}\left(\mathrm{CH}_{3}\right) \mathrm{CHC}\left(\mathrm{CH}_{3}\right) \mathrm{NAr}\right]$ and $\mathrm{R}$, as well as fuller details on the DFT calculations, are given as supporting information.

\section{$<$ Figure 2>}

The calculated BDE's are reported in Table 2. They show, in agreement with the experimental evidence, a stronger $\mathrm{Cr}^{\mathrm{III}}-\mathrm{R}$ bond for the PVAc model than for the PS model, whereas the $\mathrm{Cr}^{\mathrm{III}}-\mathrm{CH}_{2} \mathrm{Ph}$ bond has an intermediate strength. Introducing $o$-Me substituents on the $\mathrm{Ph}$ rings of the $\beta$-diketiminato ligand considerably weakens the

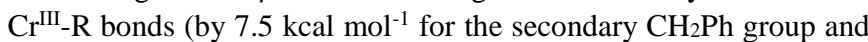
by 9.8 and $8.7 \mathrm{kcal} \mathrm{mol}^{-1}$ for the tertiary PS and PVAc models).

\section{$<$ Table 2>}

The effect of steric bulk on the $\mathrm{Cr}^{\mathrm{III}}-\mathrm{C}$ BDE is further revealed by trends in the bond lengths. Addition of the $o-\mathrm{CH}_{3}$ groups to the $\beta$-diketiminato $\mathrm{Ph}$ substituents lengthens the bond for all $\mathrm{R}$. Addition of the $\alpha-\mathrm{CH}_{3}$ group to $\mathrm{R}$ (going from benzyl to 1phenylethyl) also lengthens the bond. Conversely, replacement of $\mathrm{Ph}$ with OOCMe (going from the PS to the PVAc model) strengthens the bond, this being an electronic rather than a steric effect related to the smaller delocalization of the radical spin density These results are in perfect harmony with the inefficient PS trapping and with an irreversible PVAc trapping by the Xyl system. Extrapolation of the calculated BDEs to the Dipp system rationalizes the reversible trapping observed for the radical polymerization of VAc, showing signs of controlled growth. On the basis of these results, we are now developing new $\mathrm{CpCr}^{\mathrm{II}}\left[\mathrm{Ar}^{1} \mathrm{NC}\right.$ $\left(\mathrm{CH}_{3}\right) \mathrm{CHC}\left(\mathrm{CH}_{3}\right) \mathrm{NAr}^{2}$ ] systems with intermediate bulk.

Preliminary experiments in the presence of the isosteric complexes 3-5 indicated that the steric pressure of one Dipp and one $\mathrm{Ph}$ substituent does not sufficiently labilize the Cr${ }^{\mathrm{III}}-\mathrm{PVAc}$ bond, but revealed an unexpected electronic effect in the radical trapping rate, see Figure 3. Use of compound $\mathbf{3}$ yielded almost no polymer at $90^{\circ} \mathrm{C}$ (4\% conversion after $30 \mathrm{~h}$ ), although the $M_{n}$ and $M_{w} / M_{n}$ were low $\left(5.6 \cdot 10^{3}\right.$ and 1.15 , respectively) in agreement with a controlled process. Compound 4 gave $12 \%$ conversion within the initial $5 \mathrm{~h}$ at $60^{\circ} \mathrm{C}$, then no further increase after $40 \mathrm{~h}$ at $80^{\circ} \mathrm{C}$. However, further heating to $100^{\circ} \mathrm{C}$ yielded an increased conversion $(40 \%$ after an additional 65 h). Finally, in the presence of complex 5 an initial burst of polymerization ( $41 \%$ conversion) occurred within the first 2 $\mathrm{h}$ at $50^{\circ} \mathrm{C}$, but then conversion reached a plateau at $50 \%$ for the next $52 \mathrm{~h}$ and subsequent heating to $80^{\circ} \mathrm{C}$ took the conversion up to $71 \%$ after an additional $15 \mathrm{~h}$. It seems that the para substituent on the group ( $\mathrm{X}$ in Scheme 1) has an important effect on the alkyl radical trapping ability of the $\mathrm{Cr}^{\mathrm{II}}$ complex (barrier to bond formation in Figure 1). While the complexes containing the Xyl, Dipp and $\mathrm{Ph}$ substituents $(\mathbf{1}, \mathbf{2}$ and $\mathbf{3})$ are able to trap the growing PVAc radical chain rather effectively, those containing the $p-\mathrm{C}_{6} \mathrm{H}_{4} \mathrm{OMe}$ and especially the $p-\mathrm{C}_{6} \mathrm{H}_{4} \mathrm{CF}_{3}$ substituents (4 and 5) are much less efficient. The origin of this electronic effect is currently unknown; it is the subject of continuing investigations.

\section{$<$ Figure 3>}

In conclusion, we have shown for the first time that a $\mathrm{Cr}^{\mathrm{II}} / \mathrm{Cr}^{\mathrm{III}}$ system can provide a platform for controlled radical polymerization of less reactive monomers. The $\mathrm{Cr}^{\mathrm{III}}-\mathrm{C}$ bond strength can be tuned by accurate choice of the steric bulk on the $\beta$-diketiminato ligand. However, electronic factors affecting the rate of radical trapping must also be considered for the optimization of the OMRP process.

\section{Experimental Section}

Ligands: The symmetric $\beta$-diketiminato ligand, $\mathrm{XyINHC}(\mathrm{Me})$ $\mathrm{CHC}(\mathrm{Me}) \mathrm{NXyl}\left(\mathrm{Xyl}=2,6-\mathrm{Me}_{2} \mathrm{C}_{6} \mathrm{H}_{3}\right)$ was prepared according to the literature procedure. ${ }^{[23]}$ The mixed $\mathrm{N}$-aryl $\beta$-diketiminato ligands, $\operatorname{DppNHC}(\mathrm{Me}) \mathrm{CHC}(\mathrm{Me}) \mathrm{Ar}\left(\mathrm{Ar}=\mathrm{C}_{6} \mathrm{H}_{5}, p-\mathrm{C}_{6} \mathrm{H}_{4} \mathrm{OMe}\right.$, or $\left.\mathrm{p}-\mathrm{C}_{6} \mathrm{H}_{4} \mathrm{CF}_{3}\right)$, were prepare by reacting the appropriate aniline with $\mathrm{DppNHC}(\mathrm{Me}) \mathrm{CHC}(\mathrm{Me}) \mathrm{O}$, according to the literature procedure previously used to prepare the corresponding $\mathrm{Ar}=0-\mathrm{C}_{6} \mathrm{H}_{4} \mathrm{OMe}$ derivative. ${ }^{[24]}$

Compound 2: In a glovebox, XyINHC(Me)CHC(Me)NXyl $(2.1834 \mathrm{~g}$, $7.124 \mathrm{mmol}$ ) dissolved in $20 \mathrm{~mL}$ of THF was reacted with BuLi (3.6 $\mathrm{mL}$ of $2.0 \mathrm{M}$ solution in pentane, $7.2 \mathrm{mmol}$ ) at $-30^{\circ} \mathrm{C}$. In a separate Schlenk flask, $\mathrm{NaCp}$ (3.6 mL of $2.0 \mathrm{M}$ solution in THF, $7.2 \mathrm{mmol}$ ) was added to $\mathrm{CrCl}_{2}$ (tmeda) ${ }^{[25]}(1.7034 \mathrm{~g}, 7.124 \mathrm{mmol})$ suspended in $25 \mathrm{~mL}$ of THF at $25 \stackrel{\circ}{\circ}$. After $30 \mathrm{~min}$, the yellow solution of the deprotonated ligand was added dropwise to the reaction mixture in the Schlenk flask. After the reaction mixture had stirred overnight at $25{ }^{\circ} \mathrm{C}$, the solvent was removed in vacuo, and the residue was extracted with pentane and filtered through Celite. The solvent was again removed in vacuo, and the residue was extracted into a minimum of pentane, filtered, and cooled to $-30 \stackrel{\circ}{\circ} \mathrm{C}$ overnight to yield $1.2185 \mathrm{~g}$ of black crystals $(41.7 \%$ yield $)$. 
Compounds 3-5: Compounds 3, 4 and 5 were prepared using the same procedure as for compound 2, above, but using the $\mathrm{DppNHC}(\mathrm{Me}) \mathrm{CHC}(\mathrm{Me}) \mathrm{NAr}$ ligands, where $\mathrm{Ar}=\mathrm{C}_{6} \mathrm{H}_{5}, p-\mathrm{C}_{6} \mathrm{H}_{4} \mathrm{OMe}$, or p- $\mathrm{C}_{6} \mathrm{H}_{4} \mathrm{CF}_{3}$, respectively.

Controlled polymerizations. A general procedure was as follows Under strict exclusion of air and moisture, the reaction components (e.g. metal complex and V-70 for the OMRP runs) were placed in a Schlenk tube equipped with a stirring bar. Freshly distilled monomer and the solvent (when this was used) were added at $0{ }^{\circ} \mathrm{C}$, followed by three freeze-pump-thaw cycles. The tube was then placed in a preheated oil bath at the desired temperature. Samples were periodically withdrawn by glass syringe after quenching the solution with an icebath. The conversion was calculated by weight difference, after removing all residual monomer by evaporation under vacuum to constant weight. The polymer residue was directly analyzed by size exclusion chromatography after dissolution in THF.

Received: ((will be filled in by the editorial staff))

Published online on ((will be filled in by the editorial staff))

Keywords: Chromium - homolytic bond cleavage · ligand stereoelectronic effects - controlled radical polymerization - OMRP . poly(vinyl acetate)

[1] K. Matyjaszewski, Y. Gnanou, L. Leibler, Editors, Macromolecular Engineering: Precise Synthesis, Materials Properties, Applications, 2007.

[2] R. Poli, Angew. Chem., Int. Ed. Engl. 2006, 45, 5058-5070.

[3] M. Destarac, D. Charmot, X. Franck, S. Z. Zard, Macromol. Rapid Commun. 2000, 21, 1035-1039.

[4] M. Destarac, W. Bzducha, D. Taton, I. Gauthier-Gillaizeau, S. Z. Zard, Macromol. Rapid Commun. 2002, 23, 1049-1054

[5] M. Wakioka, K. Y. Baek, T. Ando, M. Kamigaito, M. Sawamoto, Macromolecules 2002, 35, 330-333.
[6] J. Xia, H.-J. Paik, K. Matyjaszewski, Macromolecules 1999, 32, 83108314.

[7] H.-J. Paik, M. Teodorescu, J. Xia, K. Matyjaszewski, Macromolecules 1999, 32, 7023-7031.

[8] A. Debuigne, J. R. Caille, R. Jérôme, Angew. Chem., Int. Ed. Eng. 2005, $44,1101-1104$

[9] A. Debuigne, J.-R. Caille, R. Jérôme, Macromolecules 2005, 38, 54525458 .

[10] S. Maria, H. Kaneyoshi, K. Matyjaszewski, R. Poli, Chem. Eur. J. 2007, 13, 2480-2492.

[11]A. Debuigne, Y. Champouret, R. Jérôme, R. Poli, C. Detrembleur, Chem. Eur. $J$. in press.

[12] J. C. Doherty, K. H. D. Ballem, B. O. Patrick, K. M. Smith, Organometallics 2004, 23, 1487-1489.

[13] V. C. Gibson, C. Newton, C. Redshaw, G. A. Solan, A. J. P. White, D. J. Williams, Eur. J. Inorg. Chem. 2001, 1895-1903.

[14]L. A. Macadams, W. K. Kim, L. M. Liable-Sands, I. A. Guzei, A. L. Rheingold, K. H. Theopold, Organometallics 2002, 21, 952-960.

[15]L. A. Macadams, G. P. Buffone, C. D. Incarvito, A. L. Rheingold, K. H. Theopold, J. Am. Chem. Soc. 2005, 127, 1082-1083.

[16] J. L. Conway, K. H. D. Ballem, R. Poli, B. O. Patrick, K. M. Smith, manuscript in preparation.

[17] M. Lee, Y. Minoura, J. Chem. Soc., Faraday Trans. 1 1978, 74, 17261737.

[18] M. Lee, T. Morigami, Y. Minoura, J. Chem. Soc., Faraday Trans. 1 1978, 74, 1738-1749.

[19] M. Lee, K. Utsumi, Y. Minoura, J. Chem. Soc., Faraday Trans. 1 1979, 75, 1821-1829.

[20]M. B. Gillies, K. Matyjaszewski, P.-O. Norrby, T. Pintauer, R. Poli, P. Richard, Macromolecules 2003, 36, 8551-8559.

[21] K. Matyjaszewski, R. Poli, Macromolecules 2005, 38, 8093-8100.

[22]B. B. Wayland, C.-H. Peng, X. Fu, Z. Lu, M. Fryd, Macromolecules 2006, 39, 8219-8222.

[23]P. H. M. Budzelaar, R. De Gelder, A. W. Gal, Organometallics 1998, 17, 4121-4123.

[24] A. P. Dove, V. C. Gibson, E. L. Marshall, A. J. P. White, D. J. Williams, J. Chem. Soc., Dalton Trans. 2004, 570-578.

[25] S. K. Hao, J. I. Song, P. Berno, S. Gambarotta, Organometallics 1994, $13,1326-1335$

\section{Legends}

Scheme 1. Compounds used in this study.

Figure 1. Free energy profile of controlled radical polymerizations by OMRP.

Figure 2. DFT-optimized structures of $\mathrm{CpCr}\left[\mathrm{ArNC}\left(\mathrm{CH}_{3}\right) \mathrm{CHC}\left(\mathrm{CH}_{3}\right) \mathrm{NAr}\right](\mathrm{R})$ compounds.

Figure 3. Behavior of complexes 3 (circles; VAc/V-70/3 = 250:0.9:1), 4 (triangles; VAc/V-70/4 = 500:0.9:1) and 5 (squares; VAc/V-70/5 = 250:0.9:1) as OMRP traps for PVAc. Further details are given as Supporting Information.

\section{Tables}

Table 1. Radical Polymerization of vinyl acetate initiated by $\mathrm{V}-70$ with complexes 2 and $\mathbf{1}$.

\begin{tabular}{cccccc}
\hline Complex & $\mathrm{t}(\mathrm{h})$ & Conv $(\%)$ & $M_{n S E C^{[\mathrm{a}]}}$ & $M_{n(\mathrm{th})}{ }^{[\mathrm{b}]}$ & $M_{\mathrm{w}} / M_{n}{ }^{[\mathrm{a}]}$ \\
\hline & 3.5 & 2 & - & - & - \\
& 8 & 11 & 10470 & 4730 & 1.81 \\
\multirow{2}{*}{$\mathbf{2}^{[\mathrm{c}]}$} & 18 & 12 & 10200 & 5160 & 1.86 \\
& 22.5 & 11 & 10740 & 4730 & 1.74 \\
& 48 & 12 & 11270 & 5160 & 1.67 \\
& 66 & 12 & 11270 & 5160 & 1.68 \\
\hline \multirow{6}{*}{$\mathbf{1}^{[\mathrm{d}]}$} & 3.5 & 2 & - & - & - \\
& 8 & 6 & 23800 & 2500 & 1.36 \\
& 24 & 23 & 29800 & 9900 & 1.75 \\
& 32 & 34 & 38000 & 14600 & 1.74 \\
& 46 & 70 & 67300 & 30100 & 1.80 \\
\hline
\end{tabular}

${ }^{[\mathrm{a}]}$ Determined by size exclusion chromatography $(\mathrm{SEC}) .{ }^{[\mathrm{b}]} \mathrm{M}_{n(\mathrm{th})}=\left([\mathrm{M}]_{0} /[\mathrm{Cr}]_{0}\right)^{*} \mathrm{M}_{\text {mono }}{ }^{*} \mathrm{Conv} .{ }^{[\mathrm{c}]} \mathrm{VAc} / 2 / \mathrm{V}-70=500 / 1 / 0.8 ; 50{ }^{\circ} \mathrm{C}$ for $4 \mathrm{~h}$, then $90^{\circ} \mathrm{C}$.

[c] $\mathrm{VAc} / \mathbf{1} / \mathrm{V}-70 /=500 / 1 / 0.8 ; 30^{\circ} \mathrm{C}$. 
Table 2. Calculated Cr'll-C Bond Dissociation Enthalpies $(\mathrm{BDE})^{\mathrm{a}}$ in $\mathrm{kcal}^{\mathrm{mol}}{ }^{-1}$ and bond lengths in $\AA$ for compounds $\mathrm{CpCr}{ }^{\prime \prime \prime}\left[\mathrm{ArNC}\left(\mathrm{CH}_{3}\right)\right.$ $\left.\mathrm{CHC}\left(\mathrm{CH}_{3}\right) \mathrm{NAr}\right](\mathrm{R})$.

\begin{tabular}{ccccc}
\hline & \multicolumn{2}{c}{$\mathrm{Ar}=\mathrm{Ph}$} & \multicolumn{2}{c}{$\mathrm{Ar}=\mathrm{Xyl}$} \\
$\mathrm{R}$ & $\mathrm{BDE}$ & $\mathrm{Cr}-\mathrm{C}$ & $\mathrm{BDE}$ & $\mathrm{Cr}-\mathrm{C}$ \\
\hline $\mathrm{CH}_{2} \mathrm{Ph}$ & 20.8 & 2.136 & 13.3 & 2.146 \\
$\mathrm{CH}(\mathrm{Me}) \mathrm{Ph}$ & 11.8 & 2.173 & 2.0 & 2.197 \\
$\mathrm{CH}(\mathrm{Me}) \mathrm{OOCMe}$ & 28.4 & 2.109 & 19.7 & 2.124 \\
\hline
\end{tabular}

aB3LYP/6-31G*; ZPVE and PV corrections on the basis of the ideal gas model.

\section{Entry for the Table of Contents}

\section{Chromium(III)-alkyl bonds}

Yohan Champouret, Ulrich Baisch, Rinaldo Poli, ${ }^{*}$ Liming Tang, Julia L. Conway, Kevin M. Smith, ${ }^{*}$

Page - Page

Homolytic bond strengths and formation rates in half-sandwich chromium-alkyl complexes: relevance for controlled radical polymerization<smiles>[R]c1cccc([R])c1N1[C](c2ccccc2)N(c2c([R])cccc2[R])C([R])C=C1C</smiles>

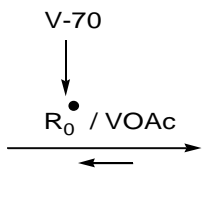

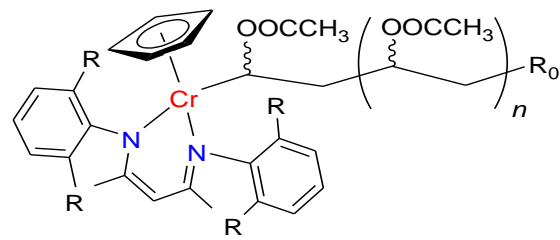

The steric properties of the aryl substituents in chromium $\beta$-ketiminato complexes can be tuned in order to achieve reversible radical trapping of a growing poly(vinyl acetate) radical chain.

\section{Graphical material}

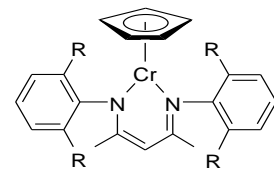

$\mathrm{R}_{1}=i-\operatorname{Pr}, \mathbf{1} ; \mathrm{Me}, 2$

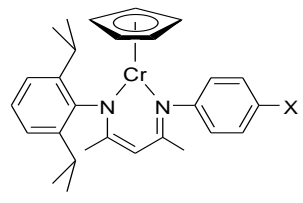

$\mathrm{X}=\mathrm{H}, \mathbf{3} ; \mathrm{OMe}^{4} \mathbf{4} ; \mathrm{CF}_{3}, 5$

Scheme 1
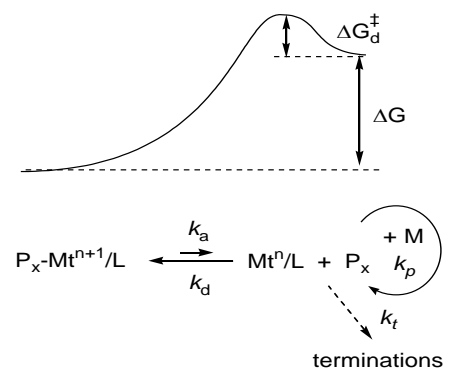

Figure 1 


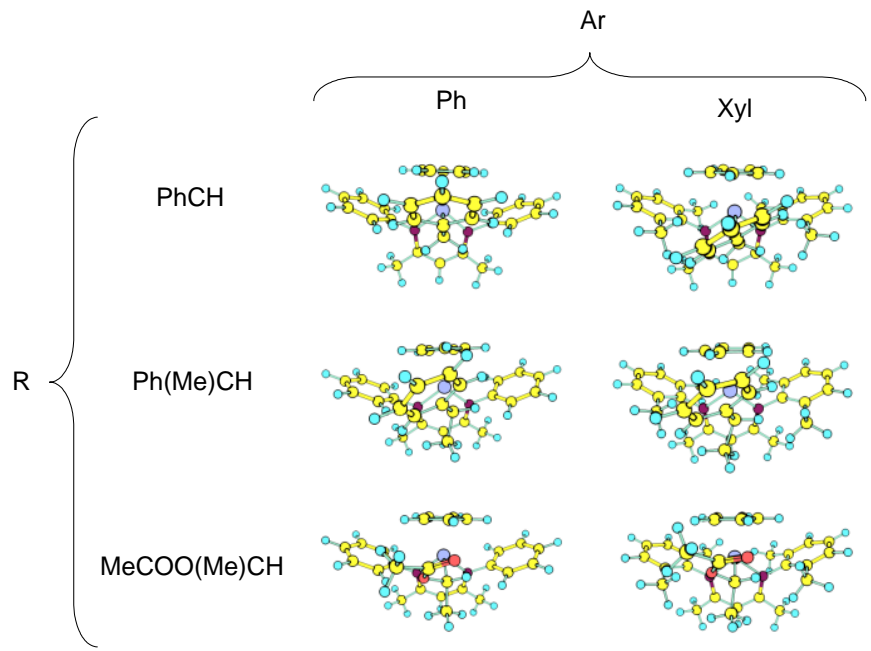

Figure 2

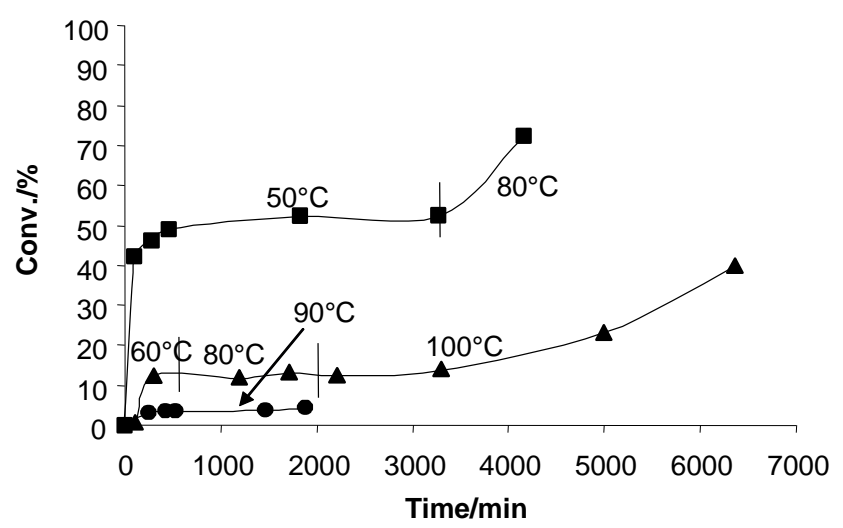

Figure 3 